\title{
Temple as the Site of Struggle: Social Reform, Religious Symbols and the Politics of Nationalism in Kerala
}

\author{
M. R. Manmathan \\ Department of History, Farook College, Calicut University, Kerala, India \\ Email: mrmanmathanmr@gmail.com
}

Received December 31 $1^{\text {st }}$ 2012; revised February 20 ${ }^{\text {th }}$, 2013; accepted February $28^{\text {th }}, 2013$

\begin{abstract}
Copyright (c) 2013 M. R. Manmathan. This is an open access article distributed under the Creative Commons Attribution License, which permits unrestricted use, distribution, and reproduction in any medium, provided the original work is properly cited.
\end{abstract}

\begin{abstract}
The temple entry movement of the 1920s and '30s in Kerala, South India, has become a landmark in the history of social reform and nationalist movements for its uniqueness and sweeping success. Popular history has presented the episode as an integral part of the Nationalist Movement and the Gandhian Constructive Programme mainly because the temple-entry issue was endorsed by the Kerala State Congress Committee and the agitation was concluded under its auspices. But this popular and idealist impression of the movement has been challenged from various quarters. It is pointed out that there have been very little attempts at linking the event with the advancing civic rights movement led by the lower caste people for freedom of worship and social equality which was gaining a radical turn by the 20s and 30s; the pressure exerted by the untouchables to achieve civic freedom even at the cost of renouncing Hinduism had created an alarming situation which no caste-Hindu could ignore. Even more surprising is the absence of academic attempts to link the agitation with the Malabar Rebellion of 1921; in fact the Rebellion had challenged the very survival of the Congress organization in Kerala; this factor forced them to retreat from the earlier secular plane to a religious idiom of politics for which the question of temple-entry served their purpose. The Temple entry movement, therefore, has to be studied in the light of the antipathy shown by the Congress towards popular and radical agitations and in the context of its growing tendency to incline towards Hindu symbols in politics as a means to escape addressing vital and burning social issues.
\end{abstract}

Keywords: Temple-Entry; Constructive Program; Vaikam Satyagraha; 1921 Rebellion; Religious Conversion; Indian National Congress

\section{Introduction}

Social reform movements of early twentieth century Kerala differed from their north Indian counterparts in certain basic features. Firstly, they overlooked individualistic and usually female-oriented reform programs and confronted inequalities among Hindu castes, which were more glaring in Kerala than anywhere else in India. At the early stages of the all-India reform movements the "evils" of society, mostly inflicted upon women-sati, the prohibition on remarriage of young widows, purdah, the custom of early marriage, and lack of educational opportunities for them-engaged the reformers' attention, and crusades for laws to protect (mostly high-caste) women and the founding of institutions to support and educate them defined the practical reform programs (Heimsath, 1978: pp. 24-26). In Kerala, women's causes never caught on ${ }^{1}$; Kerala's social evil was caste. Secondly, they were all caste/community movements;

${ }^{1}$ Mainly for the reason that society had been impregnated with mother-right cultural norms and thus women-except in Nambutiri Brahmin and some Muslim households - were already liberated. Customs like Sati, female infanticide, and the disfigurement of widows which so enraged Indian social reformers, failed to emerge from the mother-right culture of Kerala. Widow remarriage, a highly charged issue throughout India, caused no ripples either, because most low caste and Nair widows freely remarried. Among the Nambutiris mature marriage was the norm, not child marriage, and so widowhood could not claim major attention among their reformers. Infant marriages among all communities were rare. preoccupation with community-subjects marked their social presence. The process of the "construction of Hinduism" (Muraleedharan, 1996; Viswanathan, 2003), which was one of the focal points of the early social reform movements of North India, both as a desperate resistance against colonialism ("Resistant Hinduism” against “Renascent Hinduism”, Young, 1981) and as a prospective nationalist program, was only a succeeding agenda for the reformers of Kerala ${ }^{2}$. In other words, what was at stake was primarily the status relationship between communities; the formation of a unified Hindu religious community, by forging a symbolic unity of castes through the portal of the temple ${ }^{3}$, was not taken up seriously till the early 1920s. Thirdly,

\footnotetext{
${ }^{2}$ The Renaissance intellectuals focused mainly on relieving Indian religion of the features most attacked by Christian missionaries and to remodel Hindu religion in accordance with the Judeo-Christian conceptions of monotheism and anti-idolatry. This process of shaping Hindu religion according to a totally alien concept is termed as "Construction of Hinduism". "Hinduism... does not meet the fundamental requirements of a historical religion of being a coherent system; but its distinct religious entities do. They are indeed religions; while Hinduism is not” (Stietencron, 1989: p. 20) The lower caste Hindus had their own shrines (kavu), the belief system and ritual practices of which were basically different from that of the Brahmanical temples. The Izhava social reform movement was a campaign to "sanskritize" their social customs, rituals and ceremonies: Aryan gods to replace primitive deities ("to obtain high gods for lower castes", Lemercinier, 1984: p. 248), learning of Sanskrit and founding of school for Vedanta and the congregation of monks.
} 
these movements played a very insignificant part in the antiBritish nationalist opposition (Houtart \& Lemercinier, 1978: p. $5)$. The outstanding enemies here were internal, and the British colonist appeared to the depressed communities as an element favorable to their emancipation, since it was he who had been responsible for the abolition of slavery and for so many liberal reforms. For the upper castes too the British offered opportunities for emancipation, since educational progress and changes in marriage rules were largely dependent on their consent. In general, thus, the attitude of the caste associations towards the emerging nationalist movement was one of distrust and caution.

Against this background, my attempt here is to discuss how the temple-entry movement of the 1920s and '30s signified the above mentioned features and determined the nature and general course of nationalist politics in Kerala. It rejects the nationalist proposition of the temple-entry movement as a great humanitarian and philanthropic endeavor mediated by the Gandhian programme of social upliftment (Pilla, 1986: pp. 357-368; 409-415; Chandra, 1989: pp. 224-234; Menon, 2001: pp. 141163; 316-331; Menon, 1997: pp. 74, 82) towards creating a “community of equals" and places it against deep social pressures from below. In fact the episode of temple entry agitation represented a conclusive act of the movement for civil rights led by the untouchable castes from the early nineteenth century (Jeffrey, 1978a: pp. 136-169). But the Congress involvement in the struggle in the 1920s, and even later, should be examined from two political standpoints-a shrewd drive to pacify lower caste radicalism (Aloysius, 2010: p. 181) (which was aggravated by religious conversions) and to find a quick deliverance from the moral setback inflicted by the Rebellion of 1921 (which in fact threatened to destroy the very foundations of the Congress in Kerala). The highly complicated socio-political environment brought about by the rebellion problematized both the future course of nationalist political action and the status quo of existing community and class relationships upon which nationalist politics had laid its roots.

This paper, apart from examining the role of lower caste radicalism in engendering the temple-entry movement, examines the hitherto unexplored story of the impact of the 1921 Rebellion in putting pressure on the Congress to deviate from its earlier secular stance to an apparent Hindu idiom of politics. Historians have noted this point earlier (Jeffrey, 1978a; Menon, 1994) but a serious effort to develop it into a polemic has not been undertaken. My attempt here is to create a counter-narrative, not by depending on any new sets of empirical data, but through a re-reading of the existing texts, which are, however, mostly of elite origin. Sources having subaltern inclination are rare, but those that are available from the part of both the Izhavas and the Mappilas are certainly made use of; the missionary and colonial records are treated with care as they represent another set of elite sources. The paper would first trace out the social situation of nineteenth century Kerala, the long history of the movement for civil liberties and the politics of rising nationalism, and then proceed on to discuss how the temple entry agitation reflected the concerns of the caste Hindus about the growing lower caste radicalism and attempted at addressing it through social reform measures.

\section{Historiography}

Though there are plenty of literature on the civil liberties movement, the nationalist struggle and the 1921 Rebellion, and a few attempts at connecting the temple entry movement with the conversion issue, there are practically no attempts at linking it with the 1921 rebellion. The Census Reports of Travancore and Cochin from 1871 to 1941 as well as the manuals of Travancore (Aiya, 1906; Pilla, 1940) and Cochin (Menon, 1911) contain rich data on the condition of the untouchable castes. The two manuals of Malabar (Logan, 1887; Innes, 1908) discussed the role of the colonial state as instrumental in emancipating the downtrodden. Some of the anthropological studies taken up during this period (Thurston, 1909; Iyer, 1909, 1939) discussed the social condition and inter-caste relationships to analyze how customs and traditions stood to counter the engagement with modernity. We have three important pieces of missionary literature (Day, 1863; Mateer, 1871, 1883) which looked down at the "primitive" and "superstitious" customs and systems of the people of the land and placed Christianity as a great redeeming force. Two recent studies also have tried to locate missionary intervention and the presence of a powerful Christian community as decisive factors in the modernization of Kerala society (Kawashima, 1988; Onwerkerk, 1994).

Academic studies on the social and religious reform movements of Kerala in general and the Izhava reform movement in particular placed them against the existing "context" (of caste, social evils, deprivation) and the impending forces of modernity (new education, missionary activity, colonial agency and the rising middle class consciousness) and analyzed the varied factors which helped or obstructed the potential of different social groups to appropriate reformism as a means to overcome their state of deprivation. (Rao, 1979; Isaac \& Tharakan, 1988; Jeffrey, 1994). There were also attempts at examining the factors for the radicalization of the Izhava caste movement and its later inclination towards left-wing ideology (Jeffrey, 1978b). Some scholars considered missionary presence as instrumental in the gradual radicalization of the Izhava movement and the slow expansion of its emancipation agenda (Pulapilly, 1976). There were also attempts at analyzing the ideological foundations of the reform movements and to identify the unique features of the "Kerala Renaissance" (Houtart \& Lemercinier, 1978; Heimsath, 1978, 1982).

On the Malabar Rebellion we have an unending series of literature belonging to diverse ideological streams ranging from colonial to nationalist and Marxist to subaltern. Discussion on the Rebellion has generally been focused on whether they were communal or agrarian uprisings, or whether they were motivated by economic or religious imperatives. Despite "fanatical outbreak" being the predominantly shared official version of the uprisings, agrarian grievances as a possible factor did not remain totally unnoticed. Two early exponents of the religious interpretation (Conolly, Strange), while recognizing the poverty and destitution of the Mappila "fanatics", rejected them as a reason for the "outbreaks". In contrast, Logan identified agrarian discontent as the main causative factor, but underlined the turbulence and fanatical character of the Mappilas (Logan, 1887). The government held that Mappila religiosity exacerbated by nationalist politics was the prime moving force behind the rebellion of 1921 (Tottenham, 1922; Nair, 1923; Hitchcock, 1925). More recent studies have attempted to interpret the militancy of the Mappilas as a means of defending the frontier of Mappila society-internal frontier was with the Hindu society dominated by landholding Brahmins and the external frontier with the Europeans, from Portuguese to the British. The nineteenth century uprisings were jihads to defend the internal Islamic frontier. 
The rebellion of 1921 was different in that it was directed towards an identifiable political goal, i.e., establishment of an Islamic kingdom (Dale, 1980). The nationalist version is represented mainly by the autobiographical sketches of the Congress leaders which, while justifying the decision of the Congress to uphold the Khilafat issue, found fault with the government policy of repression and the irrationality and intense religiosity of the Mappilas (Nambutiripad, 1965; Nair, 1971; Menon, 1986). A dominant section of left wing historians followed an essentially economic interpretation, treating agrarian discontent as the prime factor with religion as a means of mobilization (Nambutiripad, 1952; Hardgrave, 1977; Dhanagare, 1977; Wood, 1987; Gangadharan, 1989; Panikkar, 1989). Among them Panikkar's study stood different in that it treated the context (anti-British feeling and the urge to free from the exploitation of the propertied classes) and ideology (religion translated discontent into action and provided the vision of an alternate society) equally decisive. A recent study examined the uprisings from a subaltern perspective and placed the Mappila insurgency along subalternity and religiosity, which are specific to premodern consciousness, in order to exonerate it from the alleged blemish of “communalism” and "jihadism” (Ansari, 2005).

For a survey of the nationalist movement in Kerala we have several studies, both panegyric and critical. Studies which followed the official Congress view (Pilla, 1986; Menon, 1997; Menon, 2001) perceived the shifting strands of nationalist position with reference to its primary (anti-colonial) preferences and its (umbrella-type) all-class and secular character. The disposition of the Congress in taking up the internal issues affecting class/caste relations on a secondary footing has been justified on this premise but it is further argued that the constructive program was actually devised to serve this purpose- to supplement political action through social and humanitarian work (including efforts to eradicate untouchability) — which aimed at cleansing the nation of blots which stood against true and ideal nationhood. The nationalist reading of the temple-entry movement followed such a glossy picture: uplift of the depressed sections of Hindu community through constructive program was an integral part of the work of the Indian National Congress in Kerala (Menon, 2001: pp. 141-163; 316-331). That the dual task taken up by the Congress, to build the nation and to construct a solid Hindu community, was not a mistaken strategy; in the context of the predominantly Hindu majority nation-state, the appropriation of Hindu religious symbolism was not incongruous (Chandra, 1989: pp. 230-234). A critical stream against the nationalist position came from various quarters, especially the left and the subaltern-dalit groups. The left perceived the nationalist movement as having had an implicit class agenda which got reflected in its ideology and method of political action and argued that the constructive programme was devised to establish Congress hegemony over low castes and untouchables and to pacify the mounting "pressures from below" which threatened to offset the interests of the dominant social groups who were steering the movement (Nambutiripad, 1952: pp. 131-132; Sarkar, 1990: p. 230). An article on Guruvayur satyagraha, while treating it as a part of the nationalist movement, analyzed the role of factionalism within the Congress as a possible reason for diverting the Civil Disobedience Movement (CDM) into a social struggle and attributed the failure of the struggle to the basic limitations of the Congress attitude towards untouchability (Gopalankutty, 1981). The Dalit perspective blamed Gandhi for perceiving untouchability sim- ply as a religious issue, not as a question of civil right, and hence in practice, it appeared to counter their own idea and struggles for emancipation (Aloysius, 2010: p. 181; Ravindran, 1988).

Two studies have tried to link the temple-entry agitation with the struggle for civil rights and the inner politics of the nationalist movement (Jeffrey, 1978a; Menon, 1994). While the former identified the "modernizing" impact of colonialism and the "civilizing” impact of missionary work as decisive in the creation of a powerful middle class and a congenial ideological environment leading to radicalization of the reform process, the latter discussed the difference in the degree of power and deprivation among hierarchically arranged social groups in the traditional social order and presented the nature of their response to colonialism/nationalism on the basis of the degree to which the changes which took place under the colonial system favored their emancipation/retention of privileged position.

\section{The Social Spectrum of Kerala}

The caste structure of colonial Kerala stood different from the pan-Indian scenario. The existing varna and jati system varied from the ideal four-fold model with the total absence of the Vaishyas and a very marginal Kshatriya presence; the traditional trading and commercial functions were by and large the preserve of the non-Hindu communities like the Jews, Muslims and Syrian Christians and the ruling lineages of medieval Kerala were substantially drawn from Sudra-Nair caste who however were gradually elevated to Kshatriya-Samanta status. Brahmins (including the Kerala Brahmins called Nambutiris and the immigrant Tamil and Kannada groups) constituted a mere $1 \%$ of the population of the land but they occupied the upper echelons of ritual hierarchy and owned substantial landed properties. The populous, martial and matrilineal caste of the Nairs, who were the ruling class and constituted a substantial portion of the military force in the pre-British era, were accorded higher status for being "clean sudras" which led the Brahmins to enter into alliance with them by arranging liaisons with their women ${ }^{4}$ and by entrusting them with the management of their landed estates and temples. All of the above groups along with the several tiny castes of temple-servants called Ambalavasis constituted the elite Hindus (savarna). All the castes below the Nairs were avarnas (untouchables) and included, in terms of hierarchy, the Izhavas, Pulayas, Cherumas, Parayas and Nayadis. In addition there were the fishing and tribal communities. Pulayas, Parayas and Cherumas served as agrestic laborers and occupied very low social position and economic power tantamount to serfs. Defilement practices consisting of untouchability, unapproachability and even un-seeability determined inter-caste relations and was apparently influenced by the notion of hierarchy. The savarna-avarna divide mediated by socioeconomic and political inequalities hardened and dehumanized relationships between social groups.

An examination of the position of the Izhavas in the traditional social structure reveals the range and magnitude of diverse kinds of relative deprivation. They are an ethnic category, found all over South India (Izhavas and Shannars in South Tra-

\footnotetext{
${ }^{4}$ Such conjugal alliances were called sambandham in which the male partners were just "visiting husbands" and the wives along with their children lived in matrilineal extended households maintained by impartible joint property. This practice was popular among matrilineal castes like the Nairs, Kshatriyas and Ambalavasis who had liaisons with the Brahmins.
} 
vancore, Chovans in North and Central Travancore and Cochin, Tiya in Malabar, Billava in Tulunad, Nadar in Tamil Nadu and Idiga in Mysore) and the various cognate castes in Kerala constitute a large ethnic bloc. The most popular theory is that the Izhavas were migrants from Ceylon (Aiya, 1906: pp. 398-402; Thurston, 1909: pp. 292-418; Innes, 1908: pp. 124-125; Logan, 1887: p. 80) and were Buddhists by faith (Kunhuraman, 1925; Aiyappan, 1965: p. 119). The occupation of the Izhavas in the traditional caste order was coconut plucking and toddy-tapping, though they were engaged as tenant cultivators, agricultural laborers, weavers and coir workers. They also practiced ayurveda and astrology and had a tradition of military service (Iyer, 1909: p. 298). The Izhavas ranked lower than the Nairs and above the Cherumas/Pulayas in the caste hierarchy. Though the Izhavas were at the top of the category of castes who caused distance pollution, they had to keep a distance of 36 feet from the Nambutiri Brahmins and were not allowed to enter temples managed by the upper castes. They also did not have the right to use public roads and wells of the upper castes (Aiyappan, 1944: p. 39) and were denied admission in caste Hindu schools and government jobs. Their women were not allowed to wear upper garments or any ornaments. The Nairs often demanded unpaid labour (uzhiyam) from them (Mateer, 1871: p. 43; Day, 1863: p. 322). Under the existing three-tier agrarian social structure, most Izhavas occupied the position of sub-tenants or agricultural laborers. Most of the janmis were Nambutiris, Kshatriyas or aristocratic Nairs. Kanam tenants who held the lease for a period of twelve years (but sub-leased them) were mainly Nairs. Verumpattam was the lease for a three year tenure and Izhavas and Mappilas were the prominent sub-tenants. Agricultural laborers formed an important category, and this consisted of the Izhavas, Pulayas and Cherumas.

The political attitude of the Mappila community of Malabar represented a more complex pattern. Mappilas (or Moplahs), the Muslims of Malabar, traditionally trace their origins to the ninth century, when Arab traders brought Islam to the west coast of India (Miller, 1992: pp. 40-45). By 1921, they constituted the largest - and the fastest growing - community of Malabar. With a population of one million, 32 percent of that of Malabar as a whole, the Mappilas were concentrated in south Malabar, i.e., in the Ernad, Valluvanad and Ponnani taluks of the erstwhile British Malabar described in colonial records as "fanatical zone" (Innes, 1908: p. 89). In Ernad taluk, the center of the rebellion, they formed nearly 60 percent of the population and in Walluvanad, 35 percent. The community has been characterized as consisting of pure Arab settlers, of the descendants of the Arab traders and women of the country, and of converts to Islam from the lower Hindu castes (Innes, 1908: p. 26). The Mappilas were a mercantile community concentrated along the coast in urban centers. Segregated from the Hindu population in separate settlements, they had considerable autonomy, and under the Zamorin of Calicut, they enjoyed prestige as well as economic power (Zaynu'd-Din, 1942). From the sixteenth century, with the rise of Portuguese power in challenge to Mappila commercial interests, the greater portion of the community moved into the interior of Malabar and increasingly came to be agricultural tenants, low in status and desperately poor (Dale, 1980: pp. 54-82). In sharp contrast to the general prosperity enjoyed by the Mappilas of the North (where early converts included propertied classes of the high castes), the Mappilas of South Malabar were principally converted from the lower Tiyya, Cheruman and Mukkuva castes, for whom "the honor of Islam” brought freedom from the disabilities of ritual pollution. It was in these inland areas of the south and among the poorest sections of the population that the Mappila community expanded most rapidly (Hitchcock, 1925: p. 9).

During the successive invasion of Hyder Ali and Tipu Sultan, in the late eighteenth century, Malabar was thrown into social turmoil. The Mappilas tried to reap political and economic gains from it by declaring their proprietorship rights over their tenurial lands and by remitting land tax directly to the government defying caste-Hindu landowners (Dale, 1976; Miller, 1992: p. 81; Menon, 1999). The caste Hindus responded to this hopeless situation by fleeing from Malabar and seeking refuge in the self-proclaimed Hindu state of Travancore after either disposing of their property or deserting them to the Mappilas (Narayanan \& Kesavan, 1983: p. 275). The situation was also significant in that large number of lower caste Hindus utilized the opportunity to enhance their social prestige by embracing the religion of the new rulers (Kunju, 1989: p. 79). The defeat of Tipu and the subsequent British land settlement policies in Malabar, leading to the restoration of the social and economic position of the dominant castes, severely affected the position of the Mappilas in South Malabar-by imposing enormous amount of rent and by fixing heavy renewal fees on tenurial contracts (melcharth) (Panikkar, 1989: pp. 1-48), they were oppressed in particular. Reduced to insecure tenancy, vulnerable to rack renting and eviction at the hands of Hindu janmis sustained by British courts, the Mappilas responded in a series of outbreaks ${ }^{5}$. During the course of these nineteenth century outbreaks, the number of conversions to Islam heightened dramatically. In converting to Islam, those of lower castes were not only freed from the traditional social disabilities of the outcaste, but they joined a community of resistance wherein their protest against janmi tyranny was supported by their fellow Muslims (Hardgrave, 1977: p. 62) ${ }^{6}$. The recurrent Mappila riots of the 19th century were, to a large extent, in spite of their predominant religious character (Dale, 1975), defensive responses to, or retaliatory acts against, such tyrannical acts and in that sense were essentially economic phenomena (Gough, 1968-1969). The sweeping militancy of the Mappilas and the exceptional enthusiasm they expressed in violating traditional caste dharma combined with the rise in their demographic strength intensified the

\footnotetext{
${ }^{5}$ The term "outrage" was used by the British to refer to those outbreaks of Mappilla violence in which the attack usually against a nambutiri or Nair landlord; sometimes against a European official or a convert who had slipped back into the Hindu fold and thus threatened community solidarity was followed climactically by the religious suicide of all involved, in the secure knowledge that by their martyrdom they would attain the houri bliss of Paradise. The incidents in which the mappillas "sought actively their own death”, 29 in number between 1836 and 1919, were normally suppressed in a few days and involved in each case a relatively small number of people. Only in eight of the outbreaks did more than ten Mappillas become martyrs (or shahids) (Hardgrave, 1977: p. 62).

${ }^{6}$ The Census of India, Madras (1871: p. 7) noted that the Cherumas "have to a large extent embraced Mohammedanism, and in so doing have raised themselves and their successors in the social scale. The tyranny of caste no longer affects the Mussalman converts and under these circumstances it is no cause for surprise that the Mussalman population on the Western Coast should be fast increasing”. Subsequent Census Reports recorded the continued Mappila increases and actual declines in the number of Cherumas reported. Between 1871 and 1881, the Mappila population of Malabar increased by 12.3 per cent, compared to only 3.4 per cent of non-Mappilas (Census of India, Madras, 1881: pp. 39-40). Between 1881 and 1891, Mappilas increased by 18 per cent, in comparison to a 10 per cent increase for Hindus (Census of India, Madras, 1891: p. 67).
} 
social distance between the Mappilas and the high caste Hindus (Miller, 1992: p. 98). The setback inflicted on the material interests of the dominant groups had started to articulate slowly in the form of religious polarization and in widening the communal divide.

In 1852, a special commission, headed by T. L. Strange, was appointed to investigate the causes of the outbreaks. Strange rejected the view that the disturbances had their origin in agrarian discontent or poverty and attributed it to religious fanaticism stirred by the teachings of ambitious priests. He recommended a repressive policy, enacted into law in the Moplah outrages Act, XXIII and XXIV of 1854. A special force of police was raised in Ernad to enforce these measures (Logan, 1887: pp. 570-571). The failure to quell the outbreaks despite strong police measures persuaded the government to appoint William Logan, the District Collector, as Special Commissionaire, in 1881, to enquire into land tenures and tenant rights in Malabar. Logan believed the problem to be rooted fundamentally in the early British misunderstanding of the traditional relationship of the janmi to the land. Rather than seeing the janmi as one of several agricultural classes with rights to the land and its produce, British officials viewed him as rather like an English landlord to be protected with the force of Law (Logan, 1887: p. 584). However, the government refused to implement his recommendations which is evident from the statement of District Collector Innes who writing at the turn of the century attributed the outbreaks to "three main causes, poverty, agrarian discontent and fanaticism, of which the last is probably the chief” (Innes, 1908: p. 89).

The establishment of British rule marked the beginning of a social transformation. A notable feature was the consolidation of diverse political units into larger administrative ones. By 1793 the whole of Malabar came into the hands of the British and became a district of the Madras presidency. Travancore and Cochin continued under princely rule but as subordinate allies of the British and guided by a British officer called Resident in administration. The consolidation of power in the British hands led to the introduction of a uniformity in basic legislation. Slavery was abolished in Malabar in 1843 by the British and through Royal Proclamations in Travancore and Cochin in 1853 and 1854 respectively (Basu, 2008: pp. 57, 62-63). But in the realm of land tenure and educational progress law and custom stood opposite to each other. In 1793 the British recognized the janmi as the owner of the land and kanakkar as the lease, holding a mortgage. Thus the verumpattakar tenants were dependent on their lords and if they revolted against the landlord, they were evicted. From the beginning of the nineteenth century, large number of schools was started by the Christian missionaries to impart education to the converted people. Taking queue from them, the governments of Travancore, Cochin and Malabar opened schools, but it benefitted the Nairs and the Syrian Christians. As untouchables, the Izhavas could not profit from them but the mission schools provided them openings for education. The strong anti-British attitude of the Mappilas kept them away from English education for a long time. The Tiyyas of Malabar and the Muslims of Travancore fared well and did not face much deprivation; under direct British rule, the Tiyyas could prosper educationally and socially and as traders and landowners, the Muslims of the princely states could make use of the possibilities opened up by modernity (Logan, 1887: p. 144; Iyer, 1909: p. 283).

\section{The Civil Rights Movement}

Kerala began to experience the impact of colonial modernity from the early decades of the nineteenth century, the ramifications of which were felt in the public sphere in different times and in different degrees. One of the most important impact was felt in the social realm, in the form of efforts at reforming customs and democratizing social relationships. It was the (Protestant) Christian missionaries (such as the London Mission Society (L.M.S) in Southern Kerala, Church Mission Society (C.M.S) in Central Kerala and Basel Evangelical Mission Society (B.E.M.S) in Northern Kerala) who took the pioneering steps in promoting social reforms; they actively engaged in spreading the message of reform by imparting modern education to the untouchables and encouraging the new converts to openly question symbols of caste oppression and rules of ritual pollution (Aiya, 1906, I: p. 525; Manavalan, 1990: p. 120). The revolt of the Christian converted Shannar/Nadar women of Southern Travancore to get their right to wear upper garments really shook southern Travancore in the first half of the nineteenth century (Hardgrave, 1968) ${ }^{7}$. Similarly, the activities of the missionaries and the pressure exerted by them played a decisive role in coercing the governments to abolish slavery in both Travancore and Malabar in the middle of the nineteenth century (Basu, 2008: p. 74). The missionaries were also the first to introduce print-culture in Kerala. They utilized the print media to oppose customs and practices which had contradicted with modern outlook and human reason (Anderson, 1983: pp. 41-49) ${ }^{8}$. The efforts of the missionaries had had its desired effect, especially among the lower castes, and large mass of such people became converts to Christianity. But missionary appeal failed to much impress the upper or middle level caste groups; even the untouchable caste of the Izhavas took advantage of the new opportunity and the newly acquired knowledge to attain upward social mobility within the existing Hindu social order through radical social reform (Sahodaran, 1920: pp. 290-294; Jeffrey, 1974: p. 48) ${ }^{9}$.

Early attempts at social reform were followed by organized struggle for social change which also had its genesis in the princely state of Travancore. Though being conservative and very vigilant in protecting the old social order, the government had started "modernizing" the state by founding schools, roads, law courts, and efficient bureaucracy. Meanwhile, a powerful middle class, which had been developing among the untouchable caste of the Izhavas, grew more and more frustrated over the state policy of keeping them away from government schools and service. In 1896 the Izhavas of Travancore submitted a huge memorandum (signed by 13176 men known as Izhava Memorial) calling upon the government to open public schools and services to them (Rao, 1979: p. 34). The failure of such

\footnotetext{
${ }^{7}$ The struggle is examined from various viewpoints. While some people from within the caste see it as part of an epic struggle to free the lower classes from feudal domination (Yesudas, 1975), the missionary perception take it as the triumph of decency and Christian values (Mateer, 1883: Ch.XXXIV). Hardgrave regards it as part of a wider movement within the caste order of south India for the Nadars to raise their status in the social hierarchy (Hardgrave, 1969).

${ }^{8}$ Anderson attributes the success of European Reformation to print-capitalism and stresses the coalition between Protestantism and print-capitalism.

${ }^{9}$ Sahodaran, the magazine published by the radical Tiyya lawyer C. Krishnan from Calicut, urged the Izhavas to concentrate on reforming Hinduism from within as no other religion was so liberal and tolerant. Jeffrey added that as large number of Izhavas prospered, they were able cautiously to imitate the manners of Nairs.
} 
early steps persuaded them to turn towards more radical measures under a strong organization, that is, the S.N.D.P. Yogam under the powerful leadership of Sri Narayana Guru. The Yogam took up a two-pronged struggle- the fight for social equality and freedom of worship and the internal reform of the Izhava caste to make it a model community (Pulappilly, 1976: pp. 35-39). The radical demands raised by the S.N.D.P. in Travancore, such as the freedom to use public roads and temple-entry and representation in government jobs and legislatures, and the strategy of mass struggle they adopted to achieve their demands, clearly reflected their resolve to transform-not merely to reform - the existing social structure (Heimsath, 1982: p. 33). In British Malabar, the state did not adhere to caste rules and hence the lower castes could get recruited into even higher government posts (Menon, 1901: p. 182; Kesavan, 1968: pp. 263-270). Thus the Tiyyas in Malabar were not as deprived as their Izhava counterparts in Cochin or Travancore and hence militant lower caste social reform movements failed to take roots in Malabar.

By the 1920s the movement for civil liberties was taking new proportions. As already noted, the lower caste untouchables had expressed their resolve to better their social position through mass conversion (to Christianity in southern and central Kerala and to Islam in northern Kerala) and to distance themselves with the politics of nationalism since the Indian National Congress was identified to represent upper caste interests and to perceive the colonial master as a potential ally in the path to social emancipation. But the middle level caste of the Izhavas who till then refused to experiment the possibilities of the politics of religious conversion and worked to occupy a "respected place in Hindu society" than to satisfy with a "doubtful Christian role between contemptuous Syrians and polluting Pulaya converts" (Jeffrey, 1974: p. 48), now began to seriously think of renouncing Hinduism for getting a more honorable status in the civil society. The Congress decision to uphold the cause of temple-entry stemmed from this predicament, because religious conversion was slowly growing into a vital social issue capable of subverting the existing social equilibrium solidly rooted in birth rights and hereditary social privileges.

\section{The Nationalist Politics}

The nature of political awakening in Kerala differed in the three political regions in accordance with the prevailing political climate-while in Malabar where direct colonial rule existed, nationalist movement had made deep inroads by the beginning of the Gandhian era but in the princely states of Travancore and Cochin they were at low ebb. In Travancore and Cochin, political condition of the princely state weakened the possibilities of the spread of a strong nationalist movement and hence the rising middle class of both the upper and lower castes concentrated on promoting community interests (Kesavan, 1968: pp. 356-357). This was the background of the Izhava memorial, and the Abstention Movement of the 1930s, in which various deprived groups formed a coalition forum called Joint Political Congress to press forward their middle class demands for reserved representation in government jobs and legislatures in accordance with population strength against the huge monopoly of the Nairs and Brahmins. The non-cooperation or civil disobedience movements of the 1920s and 30s did not make any political effects here; politics of the princely states evolved around social issues, skillfully masterminded by caste/community organizations.
The nationalist movement came relatively late to "sleeping Malabar". While a District Congress Committee had been formed in 1908, it was not until 1916, with the beginning of the Home Rule Movement that Malabar began to awaken politically. The fifth Malabar District Conference was held at Manjeri in 1920 with Annie Basent in chair in which the extremist group could pass a resolution in favour of tenancy reforms against the moderate stand who under Basent boycotted the proceedings. The demands for tenancy reform came principally from the class of kanakkar, substantial tenants who were largely intermediaries between janmis and the vulnerable verumpattakkar, tenants-at-will. The janmis were mostly Nambutiri Brahmins, the kanakkar were disproportionately Nairs and the verumpattakkar were overwhelmingly drawn from the Mappila community and from Tiyyas, Cheruman and other depressed Hindu castes. The Nair Kanakkar, prosperous and articulate in defense of their interests, had long been active before government commissions and in the Madras legislative assembly in efforts to secure more favorable tenancy rights for themselves. But it was not until 1920, in linking the tenancy issue with the Congress-Khilafat struggle for Swaraj, that the tenancy movement gained momentum. The Congress was still a predominantly Hindu organization, dominated largely by Nair lawyers from the kanakkar class. The rise of the Khilafat issue ${ }^{10}$ and Gandhi's decision to link it with the noncooperation movement fundamentally transformed the character of the Congress (Nambutiripad, 2005: p. 42) ${ }^{11}$.

Non-cooperation was formally launched on August 1, 1920, and on the 18th of that month Gandhi and Shaukath Ali visited Calicut to bring its message. Khilafat committees began to sprout in Malabar and official reports revealed that Mappilas of Ernad were more interested in the tenant cause and only on upholding that issue the agitators could make any advance (Tottenham, 1922: p. 4). Agrarian tension increased in the light of the rumor of an impending tenancy reforms in Malabar and while landlords increasingly evicted tenants, Nair leaders of the Congress sought to mobilize the active support of the Mappila cultivators-both for tenancy reforms and in the name of Khilafat. Intense campaigning for Khilafat scared the official circles, in the light of "fanatic outbreaks" of the past, and ignorance and backwardness of the Mappilas, which led them to ban public meetings (Madras Mail, 1921, Feb. 8: 9; Ap. 27: 8); expansion of the tenancy movement under Congress auspices spread alarm among landlords and officials alike. In the context of all these the All Kerala Provincial Congress was held at Ottappalam on 26 April 1921, in which large number of Khilafat volunteers in uniform attended (Panikkar, 1989: p. 132) and an ulema conference exhorted all Muslims to support the Khilafat as a religious duty and to join the Congress to fight for the Khilaft through the struggle for swaraj. A tenants' conference convened at Ottappalam strongly supported resistance to land-

\footnotetext{
${ }^{10}$ The Khilafat movement sought to preserve the integrity of the Ottoman Empire and the Turkish Sultan as the Caliph. The movement beginning in 1919, protested against British support for the dismemberment of the Ottoman Empire and the abolition of the Caliphate. The Indian movement was led by the Ali Brothers (Shoukath and Muhammad) but Congress soon supported the issue as Gandhi saw in it a golden opportunity to weld HinduMuslim unity and combine anti-British issue of Khilafat with the movement for Swaraj through non-violent noncooperation.

${ }^{11}$ E.M.S. wrote that a striking solidarity had developed between the Mappilas and the class of lawyers, journalists and politicians (i.e., Congressmen) who brought them into nationalist politics; both were lured by tenant interests, and looked forward to get a tenancy legislation passed.
} 
lords and Government in the form of noncooperation (Hardgrave, 1977: p. 70). Congress leaders like K. P. Kesava Menon and K. Kelappan addressed several Khiafat conferences (Menon, 1986: pp. 82-83). The "wonderful” organization of the Khilafat movement (Madras Mail, Aug. 8, 1921: p. 6) and the traditional system of communication among the Mappilas (Hitchcock, 1925: p. 3), along with the official anxiety over the Mappilas utilizing the newly forged solidarity to redress their immediate grievances (Tottenham, 1922: p. 26) forced the government to take strong punitive measures against them which, within a few days, led to the eruption of a violent uprising.

The rebellion actually started with the Tirurangadi incident in which nine Mappilas were killed in police firing while a group of 2000 people marched to the police station demanding the release of their fellowmen taken into custody during a police action at the Mambram mosque in search of some Khilafat volunteers (Hitchcock, 1925: pp. 31-34). Thereafter violence erupted which was marked by widespread attack on symbols of government authority, such as police stations, courts and record offices and cutting of railway and telegraph lines. LandlordsNambutiris and Nairs-were the principal victims of the attacks, several of whom fled from the area to the nearby towns of Calicut or Trichur. At the earliest stages, Hindus were clearly involved, but with time and growing violence (and with the proclamation of the Khilafat kingdom in south Malabar), their numbers rapidly diminished (Hardgrave, 1977: p. 83), which imparted a communal color to the rebellion. For almost six months the "Mappila zone" was under the control of the rebel leaders. The government soon resorted to reinforcements which led the rebels to retire into safe areas and to fight a guerilla war. There were frequent reports of rebel atrocities, sporadic incidence of violence against Hindus and cases of forced conversions to Islam (Nair, 1923: pp. 76-79) ${ }^{12}$. This has been attributed primarily to two factors: the impression among many rebels of the movement leading to the establishment of an Islamic state and to the widespread suspicion of Hindus acting as informants for the government (Panikkar, 1989: pp. 179, 198). By the beginning of 1922 the rebellion was crushed causing heavy casualties on the rebel side and all the leaders were soon arrested or shot dead ${ }^{13}$. Panikkar identified at least three patterns of rebel activity in the whole course of the rebellion. The initial political mobilization was effected by the Khilafat and Congress activists who were soon rendered ineffective and the actual course of the revolt thereafter developed outside the political movement in which it had initially developed. In this second, but short-lived, stage the locally influential leaders took over the direction of the rebel proceedings but ceased to be effective when the army operations began. In the third and crucial stage, the insurrection was now conducted by the rural poor themselves, either under grass-root level leadership or without any recognizable leadership at all. The pattern of rebel proceedings underlined a consciousness primarily rooted in an opposition to

\footnotetext{
${ }^{12}$ The pro-British Madras Mail was in the forefront in this venture. The antiMappila reaction was presented by the Mail in its daily reporting and in a (later) series on "The Moplah Rebellion". It referred to the "innate characteristics" of the Mappila as "his mad fanatical fury, his murderous spirit and his reckless disregard for life” (Madras Mail, 1921, Nov. 14: 5; Nov. 15: 7). Gopalan Nair's Malabar Rebellion devotes 21 pages to atrocities allegedly committed by the Mappilas against the Hindus (Nair, 1923: pp. 52-72).

${ }^{13}$ Official figures recorded 2339 rebels killed, 1652 wounded and 5955 captured. K.P. Kesava Menon estimated that as many as 10,000 may have lost their life in the rebellion (Menon, 1986: p. 116).
}

the landlord and the colonial state. Against the selective and limited nature of rebel violence (against the janmis and their servants) of the nineteenth century, in 1921 a distinction was made between the lenient and exacting landlords (although attitude towards Europeans was uniformly hostile); several of the latter category were executed and murders and physical assaults on others were largely punitive actions against collaborators and informers of the British army (Panikkar, 1989: pp. 198199).

In the context of the eruption of violence and the evolution of the revolt into a communal outbreak the Congress withdraw its support to their earlier ally, the Mappilas. The Congress leaders were in fact taken by surprise at the unexpected developments. But their activity was confined to the two trips they made to the rebel area in the early stage of the rebellion; afterwards they remained passive spectators-partly because they could not approve of the rebel action and partly because of their lack of confidence in being able to influence the rebels (Panikkar, 1989: pp. 149-151). The attitude of the Congressmen drove the Mappilas to identify the Congress with the Hindus (Panikkar, 1989: p. 189). The relief and reconstruction measures undertaken after the rebellion also underlined the communal divide-the Congress was active only among the Hindu refugees. The years that followed the suppression of the Rebellion and the withdrawal of the non-cooperation movement made it extremely difficult for the Congress organization to function in Malabar. K. P. Kesava Menon, the Congress leader, described the situation thus: "For a long time after the rebellion no public activity was possible in Malabar. Enmity towards the Congress was evident everywhere. The authorities stated that the Congress had brought down calamity on the country through participation in the Khilafat agitation. They even wanted all the Congressmen in Malabar to be imprisoned. The Muslims complained that those who had induced them to join abandoned them when police oppression and firing by the troops started” (Menon, 1986: p. 128). The caste-Hindus who were opposed to the Congress, on the other hand, denounced them for supporting the "foolish" and "fanatic" Mappilas and for inciting them to plunge into a violent action (Yogakshemam, 1921, 11: 47, 2). The Congress leadership sadly realized that the first political struggle it undertook in Kerala ended in tragedy and the alliance with the Mappilas proved self-annihilating as they not only not refused to adhere to Gandhian ahimsa but advanced it into a class and community struggle. More disturbing was the sense of unity evinced by the Mappilas and their resolve to sacrifice for a cause which was alien to the Hindu tradition and hence incompatible to "national" interests.

The Congress could not recover from the fatal blow inflicted on its morale by the rebellion for long; it could not think of political campaigning - even to summon a Congress meeting. It tried to overcome this political lethargy by focusing on the social front and by drifting towards political journalism. This was the background of the birth of the nationalist newspaper Mathrubhumi and the launching of the Vaikam satyagraha (Menon, 1986: pp. 139-149; Gangadharan, 2008: p. 248; Nambutiripad, 2005: pp. 65-68) ${ }^{14}$. The temple entry movement in fact

\footnotetext{
$\overline{{ }^{14} \text { Mathrubhumi Daily was started in } 1923 \text { from Calicut with K. P. Kesava }}$ Menon as its founder editor. Congress leaders and people sympathetic to the nationalist movement helped to raise the necessary funds. It consciously tried to propagate nationalist and patriotic sentiments as well as a spirit of Hindu unity.
} 
provided the Malabar Congressmen with a programme, and a lease of life, as it opened before them a safe field of activism; it shifted the centre of activity to further south where Mappilas were absent and furnished with a fine opportunity to compensate for the earlier "disastrous" alliance with the Mappilas by fighting for a Hindu cause (Jeffrey, 1978a: pp. 153-154) ${ }^{15}$. The Congress was turning more Hindu and more rightist; communities of foreign religious affiliation were increasingly identified as external to the national self and as threatening "national" interests.

\section{The Temple-Entry Movement}

The political and social atmosphere of Kerala in the 1920s and 30s grew tense with the Indian National Congress upholding the cause of temple entry. In 1924 the Congress organized the vigorous 20 month long satyagraha at the Vaikam temple with the simple aim of securing the right to use the approach roads of the temple for the untouchables. While the upper castes and non-Hindus including Christians and Muslims freely used the temple roads, the untouchables like the Izhavas and Pulayas were forbidden to pass through them. The Izhavas were on the verge of a revolt over the question of caste pollution and viewed it as an obvious act of social injustice and open violation of human rights. The S.N.D.P. Yogam was seriously discussing the means to overcome this social stigma. Since the Izhavas had their own temples in which they themselves acted as officiating priests, their eagerness to get access to savarna temples was more a matter of civil rights than a question of freedom of worship. T. K. Madhavan, the prominent leader of the S.N.D.P. Yogam and the true spirit behind the satyagraha, managed to get a resolution passed at the Congress session in 1923 at Kakinada on the question of the removal of untouchability. The Kerala Pradesh Congress Committee (KPCC) decided to launch a satyagraha at Vaikam on this basis (Menon, 1986: pp. 160-164). Gandhi blessed the satyagraha but cautioned against non-Hindu participation and non-savarna leadership in it as it was strictly a Hindu cause and a golden opportunity for caste-Hindus to atone for a heinous sin (Young India, 1925: p. 135; Proceedings, 1925). The satyagraha attracted countrywide attention and people from all over India reached Vaikam to support the struggle. The savarna-jatha (upper caste march) organized under the leadership of Mannath Padmanabhan to the capital Trivandrum, to impress upon the king of the urgency of the demand, truly reflected this spirit. The prolonged campaign and the direct involvement of Gandhi forced the authorities to come to a settlement according to which all the approach roads, except the eastern one, of the temple were thrown open to all people irrespective of caste and community. The modalities of the agreement was a subject of intense debate and the Congress was blamed for deserting the struggle halfway and for effecting the agreement only to the Vaikam temple (Ravindran, 1988: pp. 144-149). Due to this reason, several similar struggles had to be waged for the same purpose subsequently. As a result, in 1928, approach roads to all temples in Travancore were thrown open to all people (Menon, 1984: p. 327).

The second satyagraha struggle under the K.P.C.C. against caste based pollution, but now to get the temple open to all

\footnotetext{
${ }^{15}$ In an interview K. P. Kesava Menon revealed that for the Congressmen from Malabar district, the temple-entry campaign gave an opportunity to revive interest - at a safe distance - in a Congress that had suffered a severe setback with the Mappila rebellion of 1921 (cited in Jeffrey, 1978a: pp. 153-154).
}

Hindus, was organized in 1931-32, in the course of the C.D.M, at the Guruvayur temple in Malabar. While the struggle at Vaikam was a social reform measure divorced from any political movements, at Guruvayur it was integral to a political program (Gopalankutty, 1981). Nevertheless, in Kerala, the zeal for social reform overshadowed the rising countrywide political enthusiasm; for the K.P.C.C. the temple-entry issue was more important than the C.D.M. and leaders like Kelappan concentrated heavily on the question of untouchability (Mathrubhumi, 1931, Ap. 6, June. 21, July. 29, July. 31 \& Sep. 10; 1932, March. 5, March. 27 \& Aug. 4). Gandhi also asked the satyagrahis to detach the struggle from all its political affiliations and from the organizational links of the Congress in order to rescue it from government repression and to ensure its success. Though the temple-entry agitation was perceived as tantamount to the "struggle against imperialism" by some of its leaders (Gopalan, 1973: p. 28) as it kept vigil against disunity and factionalism, what really prompted the Congress to confine the struggle to temple-entry was the bitter experiences of $1921^{16}$. The Zamorin, who was the trustee of the temple, however, refused to step down to negotiate a settlement which led Kelappan to start a fast unto death which, however, was withdrawn under the advice of Gandhiji (Mathrubhumi, 22 Sep. \& 4 Oct. 1932). The satyagraha as a whole was finally terminated before achieving any of its declared objectives. A period of three months was given to the Zamorin to effect temple-entry, failing which Gandhi would himself offer satyagraha; but it was postponed and did not take place at all. A referendum was held among the caste Hindus of Ponnani taluk, where the temple was situated, which revealed that $70 \%$ of them supported the cause of temple entry (Mathrubhumi Weekly Temple Entry Special Issue, 16 Nov. 1937). N.P. Damodaran, one of the leaders of the satyagraha, later recollected that though the agitation failed to meet its immediate objective, it created a climate in favour of temple entry (Damodaran, 1981). The movement for temple entry registered its crowning victory when the Travancore government made the temple entry proclamation in 1936 by which all temples in Travancore were thrown open to all Hindus (Menon, 1984: pp. 327-328). Nevertheless, the temples of Cochin and Malabar remained closed before the avarnas till 1947.

\section{Politics of the Temple-Entry Movement}

The temple-entry movement was important for several reasons. Firstly, it was a conscious effort on the part of the Congress to integrate the various castes and communities under the Hindu fold through social and religious reform, which represented a powerful domain of the nationalist movement. Temple could rally diverse sections together without dislodging the existing power relations and a symbolic unity could pacify lower caste radicalism. The Congress decision to take up the issue in Kerala was certainly in the context of the inclusion of the removal of untouchability as part of the Gandhian constructive program and its decision to fight out social evils in accordance with the nation-building project, but the constructive

\footnotetext{
${ }^{16}$ The fear of the Mappilas loomed large even in the 30's and during the salt march it is reported that salt law had been broken all over Malabar except in the erstwhile "rebel" areas. Moreover, the procession on foot from Payyannur, heading for the Guruvayur satyagraha stopped short of the "rebel” area. The marchers took a train from Feroke to Tirur "because of a rumor that the Mappilas would prevent them from moving into Ernad” (Menon, 1994: pp. 103-104).
} 
programme itself betrayed its elitist character (Kooiman, 1995: p. 45; Onwerkerk, 1994: p. 56). Writings of Gandhi in the early twenties, and even later, revealed how the Congress leadership was getting seriously troubled by lower caste radicalism and the increasing volume of religious conversions (Young India, 27.10. 1920: 135; 04.06.1925: 135; 19.01.1921: 6; 04.05.1921: 3; 27. 04.1921: 5; 22.09.1921: 11; 29.09.1921: 12; 13.10.1921: 13; Harijan, 11.02.1933; 31.10.1936) ${ }^{17}$. Of equal importance was the basic limitation of the anti-untouchability program: it searched for a moral solution to repair inequalities to recast the nation but without dislodging the basic social structure ${ }^{18}$. The Congress leadership in Kerala also refused to address the economic content or power relationships rooted in it but rather took it as a question of equality within religion and an unfortunate aberration from scriptural injunctions.

Secondly, the heated debates unleashed by the Izhava middle class on religious conversion was acquiring political and economic dimensions. C.V. Kunhuraman, the firebrand leader of the S.N.D.P. and the editor of Kerala Kaumudi had made the alarm signal by urging the Izhavas to renounce Hinduism if the upper castes did not support their cause of temple entry (Kunhuraman, 1936). A section of the Izhavas enthusiastically welcomed the suggestion. Though there were differences of opinion as to which religion they should opt-whether Christianity, Islam or Buddhism - the challenge fell like a bombshell on the savarna groups. Although conversions had been taking place among the untouchables from very early times and its pace had considerably increased by the nineteenth and early twentieth centuries, the ' 20 s and ' 30 s were special because now the challenge came from the Izhavas who though "are avarnas are rich and educated" (Kelappan, 1925). The loss of the middle class was exceptionally harmful as they could threaten-as in the case of the Christian middle class of central Travancore (Jeffrey, 1978a: pp. 153-154) - the material pursuits of the upper caste Hindus. A powerful section within the S.N.D.P-including Kumaran Asan, T. K. Madhavan and A. Ayyappan, and of course Sri Narayana Guru too-stood for a reformed Hinduism (Kesavan, 1968: pp. 274-276). But radicals held fast to the idea of conversion; preferably to Buddhism against the Sri Lankan background of the Izhavas (Kunhuraman, 1925); this had lent

\footnotetext{
${ }^{17}$ In a series of articles entitled "The Removal of Untouchability" wrote in Young India and Harijan, Gandhi viewed conversion rather more inspired by the desire for material benefits than for spiritual needs. The lower caste people were getting converted because of untouchability which has to be eliminated not only to cleanse Hinduism of its evils but to attain swaraj also. Foreign rule in India is a divine punishment for following this curse which "is a crime against god and humanity". In fact untouchability was not a part of original Hinduism and hence those who threaten to abandon Hinduism are deceiving their religion. He consoled the untouchables that their low social stature is not due to their fault and urged the savarna people to take up the removal of untouchability as an act of atonement before they were too late to do so.

18“"Untouchability was both a moral and political problem: the former because its eradication involved undermining its moral legitimacy and changing, or at least softening, Hindu attitudes; the latter because it was deeply rooted in the highly unequal structure of power relationship between the upper castes and the harijans and could not be removed without restructuring it. It had therefore to be fought at both levels. Gandhi's campaign was conducted only at the moral and religious level. Hence he concentrated on caste Hindus..., appealed to their sense of duty and honor, mobilized their feelings of shame and guilt, and succeeded in achieving his initial objective of discrediting untouchability and raising the level of the Hindu... consciousness. Since he did not organize and politicize the harijans, stress their rights and fight for a radical reconstruction of the established social and economic order, Gandhi's campaign was unable to go further" (Parekh, 1989: pp. 245-246).
}

space to speculations, that the conversion issue was a pressure tactic to enforce a reform of customs. However, it had its desired effect: caste Hindus increasingly began to realize the need of ritual reform which is evident in the rhetoric against conversions with a stress on the innate quality of Hinduism (Thampan, 1932; Nambutiripad, 1932). The Nair aristocracy fanned Nair communal passions against the Christian capitalists who were buying up their land and prestige (Isaac \& Tharakan, 1988: p. 166). Leaders like "Mannam, who was not a Gandhian and was in general opposed to the Congress", participated in the Vaikam Satyagraha for his concern over the loss to Hinduism of converts to Christianity (Onwerkerk, 1994: p. 59). The temple entry movement under the leadership of the Congress thus represented an attempt at forging a consolidated Hindu identity and to discourage conversions which was engendered by disabilities enforced by the caste system. Religious conversion could cause trouble to the caste Hindus because "it reduced their rhetorical constituency” (Jeffrey, 1978a: p. 143). The writings of Kelappan clearly demonstrated how the temple-entry movement was directly linked to the threat posed by religious conversions (Kelappan, 1925; 1932a; 1932b) ${ }^{19}$.

Thirdly, the Congress interest in the temple-entry struggle was an attempt to offset the damage caused to its prestige and honor by the incidents of 1921 . Congress leadership tried to escape from the initial shock by expressing its "firm conviction" that the non-cooperation and Khilafat movements were in no way responsible for the outbreak. The Congress view was recorded in the resolution of the Working Committee in September 1921, expressing a "sense of deep regret over the deeds of violence done by the Mappilas in certain areas of Malabar" and resolved that the rebellion was not caused by the Khilafat or Non-cooperation movements, and that the causes of the rebellion had nothing to do with these movements (Sitaramayya, 1946: p. 216). Prominent Congress leaders in Kerala shared this view as is understood from Kesava Menon's comment that “it was wrong to have connected the Khilafat problem with the Nationalist Movement” (Menon, 1977: p. 48). Congressmen in Kerala were under siege for upholding the Khilafat issue and forging an alliance with the "fanatic" Mappilas which brought about "great hardships to the Hindus and dishonor to the land". The committees appointed by the Congress failed to make a comprehensive and objective enquiry into the cause of the rebellion, which led to develop controversies with strong political and communal overtones. K. Moidu Maulavi, Khilafat leader and staunch nationalist, reiterated his firm conviction that the rebellion was a struggle for freedom, it started as an anti-imperialist rising, although "in the end the British authorities had succeeded to an extent in degrading it into a communal conflict” (Maulavi, 1981: pp. 136-141; 152-154). But Kesava Menon stated (later) that it would not be correct to consider the "Mappila Rebellion" as part of the Nationalist movement because the rebels "were motivated more by religious zeal and

\footnotetext{
${ }^{19} \mathrm{~K}$. Kelappan, the great Gandhian Congressman and the foremost champion of the temple-entry movement in Kerala, in his article on the Vaikam Satyagraha (1925: pp. 42-45), justified the struggle in the context of the increasing tendency of the lower castes, especially Izhavas, to renounce Hinduism. In another article written around the time of the Guruvayur Satyagraha, he expressed great concern over the harms caused by conversions. This article is specially noted for his attitude of the Muslim "other"; they are perceived as a threat to the nation and national unity; mainly because of their solidarity and stress on international brotherhood (1932a: pp. 7-8). He also suggested a "secular" programme the government should follow to curb the growth of (Muslim) communalism (1932b: pp. 4-5, 10).
} 
interest in the Khilafat than by true national consciousness" (Menon, 1977: p. 48). In their highly illuminating accounts of the event, two other prominent Congress leaders-K. Madhavan Nair and Mozhikunnath Brahmadathan Nambutiripadtraced the origin of the rebellion back to the high-handed British policy of repression (Nair, 2002; Nambutiripad, 1965). By attributing the violence of 1921 to the official atrocities, they justified the decision of the Congress to ally with the Mappilas but regretted for associating with a group still unfit for a modern and secular political struggle-and thus justified the official Congress position rejecting the struggle as a part of the national movement. They also shared the colonial perception of the uprising as nothing but a "riot" and treated the Mappilas as "wild" and "fanatic" people who could not be trusted or easily tamed.

Neither did the rebellion confine its impact to Malabar politics alone. The widespread propaganda recounting awesome details of the "Hindu suffering" at the hands of the Mappila rebels gave birth to an aggressive Hindu campaign, at first against the "cruel Mappilas" and later against Muslims in general. On the other hand, the sufferings of the Mappilas deeply moved Muslims all over India. Frantic appeals for helping them received generous response from the North. All these affected the relationship between the Hindus and Muslims all over India. "The exaggerated tales (about the rebellion)... inflamed feelings. The cry of Hinduism in danger was raised and movements of Shuddhi (reconversion) and Sanghathan (organization) planned. A vicious cycle of accusation and counter-accusation was set up which created the heat in which the tender plant of Hindu-Muslim unity began to wither” (Chand, 1972: p. 497). The "communal antagonisms generated by the Malabar Rebellion” (Brown, 1972: p. 329) and the steadily advancing nationalist discourse centered on religious and cultural nationalism greatly strengthened the concept of the Muslim "other" to the extent that even the great Izhava reformer and poet Kumaran Asan wrote a tale of the Rebellion villainizing the Mappilas in which he told the tale of a Nambutiri girl thrown desolate by the "cruel Muhammedans" during the revolt of 1921 (Asan, 1969). Similarly, in his "statement” attached to the 1970 edition of K. Madhavan Nair’s Malabar Rebellion, K. Kelappan shared the concern of the Congress leadership towards the "minority Hindus of Ernad" against the "illiterate”, "ignorant" and hence “rude” Mappilas (Nair, 2002: ix-xii) ${ }^{20}$.

The fear of the Mappilas for their "lack of civility", the widespread concern over the hardships of the (upper caste) Hindus who had escaped from the affected areas to take shelter in the nearby town of Calicut or in the princely states of Travancore and Cochin, the cooperation extended by Congress to the relief measures undertaken by the Arya Samaj, which was also very active in reconverting the Hindus who were converted to Islam, (Ansari, 2005: p. 64) the total breakdown of the organizational structure of the Congress and its inability to carry on even normal political activity in the face of official retribution and

\footnotetext{
${ }^{20}$ Chatterjee (1995: p. 126) writes that the fact that Indian nationalism is synonymous with "Hindu nationalism" is an entirely modern, rationalist and historicist idea. The notion of "Hinduness" is not defined by any religious criteria at all. There are no specific beliefs or practices which characterize this "Hindu" and the many doctrinal or sectarian differences among Hindus are indifferent to this concept. Even anti-Vedic and anti-brahmanical religions as Buddhism and Jainism count here as "Hindu". Clearly excluded from this jati are religions like Christianity and Islam. The criterion for inclusion and exclusion is determined by their historical origin. Buddhism and Jainism are 'Hindu' because they originated in India while Islam and Christianity originated outside and are, therefore, foreign.
}

popular distrust in its programs, all forced the Congress to retreat to a Hindu idiom of politics (Menon, 1994: p. 78). Gandhi's statement-“The Moplahs are Muslims"-reveals the stereotypical character-construct of the Muslim (Ansari, 2005: p. 73). The leadership of the Congress in Kerala could not get out of the shock inflicted by the events of the rebellion, especially the attack of the Mappila rebels on caste Hindus. This was not surprising because in Malabar caste system conformed to a kind of class order: the caste Hindus were the landlords or the prominent leaseholders of the area while the Mappilas were the sub-tenants under them (Panikkar, 1984). Among the higher castes in particular, it is observed, the attitude towards Islam was coloured by the way in which Islam impinged upon their interests (Misra, 2004: p. 20). That the lower caste tenants refused to rebel against their upper caste lords in Malabar clearly revealed the manner by which caste hierarchy and the mode of class response got enmeshed. The higher castes could realize that the threat posed by conversion to their interests could only be countered by bringing various caste groups together on some common issue and by reforming social practices which segmented them; efforts to forge a symbolic unity among Hindu communities around the question of temple-entry appeared a useful weapon to discourage the untouchable castes to get attracted to religions which promised to emancipate them. For the dominant groups, religion offers the necessary ideological justification for existing social divisions, makes these divisions appear non-antagonistic and holds together a potentially divided society into a single whole (Chatterjee, 1989: p. 172).

Thus, the championing of the temple-entry cause (mainly at Vaikam) provided the Congress with a big lease of life: it gave a platform for action with a strictly non-political program; it saved them from official surveillance as the centre of activity was shifted to the safe environs of the princely state of Travancore; it eschewed the fear of communal tension because the Mappila factor was absent in Travancore (Menon, 1994: pp. 103-104) and above all, it provided the Congress with an opportunity to expiate for the "sin" of allying with the "dangerous” Mappilas by upholding a "Hindu” cause. Congressmen played the role of an arbiter between various Hindu castes, which in fact signaled a retreat from secular political activity, but it opened before them a program of action after the "Mappila” rebellion (Menon, 1994: p. 80).

\section{Conclusion}

The temple-entry movement decided the future course of politics in Kerala at least in three respects. Firstly, it provided a conclusive end to the civil rights movement undertaken by the untouchable castes leading to the attainment of the right of universal temple-entry. The questions of religious disability and freedom of worship slowly subsided to become less and less powerful to command the discourse of civic life and political culture. The debates centered on religious conversion as a means of social emancipation also faded out altogether (Isaac \& Tharakan, 1988: p. 168; Narayanan, 2011). The (upper caste) leadership of the Congress was able to coerce the caste-Hindus to compromise on the question of temple-entry as the only viable means to ward off religious conversion which challenged the very survival of the Hindu community. Secondly, with the success of the temple-entry agitation the conversion movement certainly began to wane in Kerala, but it greatly undermined the secular image of the Congress for its propagandist role in dis- 
seminating the so-called "Essentials of Hinduism" and in seeking to forge a (Hindu) "community of equals" (Menon, 1994: p. 80) through a common bond of religiosity and uniformity of religious worship around temples. In that sense the templeentry movement marked a definite stage in the process of the disjunction of folk religion and other currents of religion. Religion is no longer divided into lower religion and higher religion, but into religion and superstition (Sontheimer, 1995: p. 396). Hence it was a shuddhi movement-to cleanse religion of blots identified incompatible with modernity and the essentials of nationhood. The temple-entry satyagraha attains significance against the dual task taken up by the Indian National Congress - to construct a modern nation-state and to mould a national (Hindu) religion. But it had its disastrous consequences-in driving religious minorities away from the organizational fold and ideological appeal of the Congress. The bitter experiences of 1921 followed by the conscious involvement of the Congress in the affairs of religious nationalism forced the Mappilas to keep away from nationalist politics and slowly drift towards a marked sectarian identity. The slow but steady drift of the Mappilas into communal politics became inevitable (Panikkar, 1989: p. 190). Thirdly, the struggle for temple-entry helped in delivering the Congress from the moral setback it faced after the Malabar rebellion, but in the unique social context of Kerala where reform movements had succeeded in shaping an ideological environment in favor of social equality, its withdrawal from direct politics to engage with socio-religious issues, disregarding more important questions of material deprivation and class disparities, transcending caste/religious affiliations, reduced its political constituency and created a fertile ground for the proliferation of left political ideology in subsequent times. Moreover, in the 1930s, the strong communal and caste consciousness let loose by the agitation against caste disabilities could lead the poor towards class consciousness (as caste roughly coincided with class in Kerala). With the Temple entry Proclamation in Travancore in 1936- "the final act in the embourgeoisment of society" as Nambutiripad saw it (Jeffrey, 1978: p. 82) — the middle class members were accorded the right to use temples and abruptly lost interest in the poor of their own caste. But the political excitement awakened among the poor and low caste could not be made to go away; it lay ready to be developed into class consciousness.

\section{REFERENCES}

Newspapers/Periodicals

Harijan

Madras Mail

Mathrubhumi Daily

Mathrubhumi Weekly

Mitavadi

Sahodaran

Yogakshemam

Young India

Government Publications

Aiya, V. N. (1906). The Travancore State manual, I\&II. Trivandrum: Travancore Government Press.

Cornish, W. R. (1874). The census of India 1871, Madras Vol. I, Report. Madras: Government Press.

Hitchcock, R. H. (1925). A history of the Malabar rebellion, 1921. Madras: Government Press.

Innes, C. A. (1908). Madras District gazetteers, Malabar I. Madras: Government Press.

Logan, M. (1882). Report of the Malabar special commission 1881-2, I.
Madras: Government Press.

Logan, W. (1887). Malabar manual, I. Madras: Government Press.

McIvery, L. (1883). Census of India, 1881, Madras, Vol. I, Report. Madras: Government Press.

Menon, C. A. (1911). Cochin State manual. Ernakulam: Government Press.

Menon, M. Sankara. (1901). Census of India, Vol. 20 (Cochin) Part I (Report). Ernakulam: Government Press.

Pillai, T. K. V. (1940). Travancore State manual, Vol. I. Trivandrum: Travancore Government Press.

Proceedings of the Conference held at Mr. Idamturuttil Devan Neelakantan Nambutiripad's House, Vaikam on 10 March 1925. Correspondence on the Vaikam Satyagraha, Vol IX, English Records, Secretariat, Trivandrum.

Stuert, H. A. (1893). Census of India, 1891, Madras, Part. I Report. Madras: Government Press.

Tottenham, G. R. F. (1922). The Mappila rebellion, 1921-22. Madras: Government Press.

\section{Autobiographies}

Kesavan, C. (1968). Jeevitasamaram. Kottayam: National Book Stall.

Maulavi, M. (1981). Atmakatha. Kottayam: SPCS/National Book Stall.

Menon, K. P. K. (1986). Kazhinja Kaalam. Calicut: Mathrubhumi Books.

Nambutiripad, E. M. S. (2005). Atmakatha (6th ed.). Thiruvananthapuram: Chintha Publishers.

Books

Aiyappan, A. (1944). Iravas and culture change. Madras Government Museum Bulletin, 1.

Aloysius, G. (2010). Nationalism without a nation in India. New Delhi: Oxford University Press.

Anderson, B. (1983). Imagined communities: Reflections on the origin and spread of nationalism. London: Verso Editions and NLB.

Ansari, M. T. (2005). Refiguring the fanatic: Malabar, 1836-1922. In S. Mayaram, M. S. S. Pandyan, \& A. Skaria (Eds.), Subaltern studies, XII (pp. 36-77). Delhi: Permanent Black and Ravi Dayal.

Asan, K. (1969). Duravastha (Distress). Trivandrum: Sarada Book Depot (Rpt)

Brown, J. M. (1972). Gandhi's rise to power: Indian politics, 19151922. Cambridge: Cambridge University Press.

Chand, T. (1972). History of the freedom movement in India, III. New Delhi: New Delhi Publications Division, Government of India.

Chandra, B. (1989). India's struggle for independence 1857-1947. New Delhi: Penguin Books.

Chatterjee, P. (1989). Caste and subaltern consciousness. In R. Guha (Ed.), Subaltern studies: Writings on South Asian history and society, No. 6 (pp. 169-209). Delhi: Oxford University Press.

Chatterjee, P. (1995). History and the nationalization of Hinduism. In V. Dalmia, \& H. Von Steitencron (Eds.), Representing Hinduism: The contraction of religious tradition and national identity (pp. 103-128). New Delhi: Sage Publications.

Cooiman, D. (1995). Communities and electorates: A comparative discussion of communalism in colonial India. Amsterdam: V.U. University Press.

Dale, S. F. (1980). Islamic society on the South Asian frontier: The Mappilas of Malabar, 1498-1922. Oxford: Clarendon Press.

Day, F. (1863). The land of Perumals or Cochin and its past and its present. Madras: Oantz Brothers at the Adelphi Press.

Gangadharan, M. (2008). The Malabar rebellion. Kottayam: D.C. Books.

Hardgrave Jr., R. L. (1969). The Nadars of Tamilnad: The political culture of a community in change. Berkeley: University of California Press.

Isaac, T. M. T. \& Tharakan, P. K. M. (1988). Sree Narayana movement in Travancore. In S. K. Sreevastava \& L. Sreevastava (Eds), Social movements for development (pp. 155-177). Allahabad: Chugh Publications.

Iyer, L. A. K. (1909). The Cochin Tribes and castes. Madras: Higginbotham's.

Iyer, L. A. K. (1939). The Travancore Tribes and castes. Trivandrum: Government Press.

Jeffrey, R. (1978a). Travancore: Status, class and the growth of radical 
politics, 1869-1940-The temple entry movement. In R. Jeffrey, (Ed.), People, princes and paramount power: Society and politics in the Indian princely states (pp. 136-169). Delhi: Oxford University Press.

Jeffrey, R. (1994). Decline of Nair dominance: Society and politics in Travancore, 1847-1908. New Delhi: Manohar.

Kawashima, K. (1988). Missionaries and a Hindu state: Travancore 1858-1936. New Delhi: Oxford University Press.

Kunhuraman, C. V. (1936). Izhavarude mathaparivarthana samrambham (Religious conversion enterprise of the Izhavas). Kottayam: Kaumudi Press.

Kunju, A. P. I. (1989). Mappila Muslims of Kerala. Trivandrum: Sandhya Publishers.

Lemercinier, G. (1984). Religion and ideology in Kerala. Delhi: D. K. Agencies.

Manavalan, P. (1990). Kerala samskaravum Kraistava missionarimarum (Kerala culture and Christian missionaries). Kottayam: DC Books.

Mateer, S. (1871). The land of charity: A descriptive account of Travancore and its people. London: John Snow \& Co.

Mateer, S. (1883). Native life in Travancore. London: W. H. Allen \& Co.

Mathew, G. (1989). Communal road to a secular Kerala. New Delhi: Concept Publishing Company.

Menon, A. S. (1984). A survey of Kerala history. Madras: S. Viswanathan Pvt Ltd.

Menon, A. S. (1997). Kerala and the freedom struggle. Kottayam: D.C. Books.

Menon, D. M. (1994). Caste, nationalism and communism in South India: Malabar, 1900-1948. New Delhi: Cambridge University Press.

Menon, K. P. K. (1977). Some aspects of the nationalist movement in Malabar. In K. P. S. Menon (Ed.), Kesava Menon (pp. 43-48). Calicut: K. P. Kesava Menon 90th Birthday Celebration Committee.

Menon, P. K. K. (2001). History of the freedom movement in Kerala, Vol. II. Thiruvananthapuram: Department of Cultural Publications.

Menon, M. G. (1989). Malabar rebellion, 1921-1922. Allahabad: Vohra Publishers.

Miller, R. E. (1992). Mappila Muslims of Kerala: A study in Islamic trends. Madras: Orient Longman.

Misra, A. (2004). Identity and religion: Foundations of anti-Islamism in India. New Delhi: Sage Publishers.

Nair, G. G. (1923). The Moplah rebellion, 1921. Calicut: Norman Printing Bureau.

Nair, K. M. (2002). Malabar kalapam (Malabar rebellion). Calicut: Mathrubhumi Books.

Nambutiripad, E. M. S (1952). The national question in Kerala. Bombay: People's Publishing House.

Nambutiripad, M. B. (1965). Khilafat smaranakal (Khilafat reminiscences). Kozhikkode: Navakerala Co-operative Publishing House.

Narayanan, M. G. S., \& Kesavan, V. (1983). A history of the Nambutiri community in Kerala. In F. Stall (Ed.), Agni: The Vedic ritual of the fire altar (pp. 256-278). Delhi: Motilal Banarsidas.

Onwerkerk, L. (1994). No elephants for the Maharaja: Social and political change in Travancore 1921-47. New Delhi: Manohar Publishers.

Panikkar, K. N. (1984). Peasant exploitation in Malabar in the nineteenth century. Journal of Kerala Studies, 11, 155-185.

Panikkar, K. N. (1989). Against lord and state: Religion and peasant uprising in Malabar, 1836-1921. Delhi: Oxford University Press.

Parekh, B. (1989). Colonialism, tradition and reform: An analysis of Gandhi's political discourse. New Delhi: Sage Publications.

Pilla, A. K. (1986). Congressum Keralavum (Congress and Kerala). Trivandrum: Prabhath Book House.

Rao, M. S. A. (1979). Social movements and social transformation: A study of two backward classes movement in India. Delhi: MacMillan.

Ravindran, T. K. (1988). Vaikam satyagraha and Gandhi. Trivandrum: Sri Narayana Institute of Social and Cultural Development.

Sarkar, S. (1990). Modern India, 1885-1947. Madras: Macmillan.

Sitaramayya, P. (1946). The history of the Indian national congress 1885-1936. Bombay: Padma Publications Ltd.
Sontheimer, G. D. (1995). The erosion of folk religion in modern India: Some points for deliberation. In V. Dalmia, \& H. Von Steitencron, (Eds.), Representing Hinduism: The contraction of religious tradition and national identity (pp. 389-398). New Delhi: Sage Publications.

Thurston, E. (1909). Castes and tribes of southern India, II. Madras: Government Press.

Viswanathan, G. (2003). Colonialism and the construction of Hinduism. In G. Flood (Ed.), The Blackwell companion to Hinduism (pp. 23-44). Oxford: Blackwell. doi:10.1002/9780470998694.ch2

Von Stietencron, H. (1989). Hinduism: On the proper use of a deceptive term. In G. D. Sontheimer, \& H. Kulke (Eds.), Hinduism reconsidered. Delhi: Manohar.

Wood, C. (1987). The Moplah rebellion and its genesis. New Delhi: People's Publishing House.

Yesudas, R. N. (1975). A people's revolt in Travancore: A backward class movement for social freedom. Ernakulam: Kerala Historical Society.

Young, R. F. (1981). Resistant Hinduism: Sanskrit sources on antiChristian apologetics in early nineteenth century India. Vienna: De Nobili Research Library.

Zaynu'd-Din, S. (1942). Tuhfat-al-Mujahidin. Translated by S. M. H. Nainar. Madras: University of Madras.

Articles

Basu, R. S. (2008). Pulayas in Kerala: The nineteenth century emancipation question re-explored. The ICFAI University Journal of History and Culture, 2, 47-76.

Dale, S. F. (1975). The Mappila outbreaks: Ideology and social conflict in nineteenth century Kerala. Journal of Asian Studies, $X X X V$, 85-97.

Dale, S. F. (1976). The Mappilas during Mysorean rule: Agrarian conflict in eighteenth-century Malabar. South Asia, 6, 1-13.

Damodaran, N. P. (1981). Oru sathyagrahathinte katha (The story of a satyagraha). Mathrubhumi Weekly, 22-25.

Dhanagare, D. N. (1977). Agrarian conflict, religion and politics: The Moplah rebellion in the nineteenth and early twentieth centuries. Past and Present, 74, 112-141. doi:10.1093/past/74.1.112

Gopalankutty, K. (1981). The Guruvayur satyagraha, 1931-32. Journal of Kerala Studies, 8, 43-55

Gough, K. (1968-1969). Peasant resistance and revolt in South India. Pacific Affairs, XVI, 526-554. doi:10.2307/2754563

Hardgrave Jr., R. L. (1968). Breast cloth controversy: Caste consciousness and social change in southern Travancore. Indian Economic and Social History Review, 5, 171-187.

Hardgrave Jr., R. L. (1977). The Mappilla rebellion, 1921: Peasant revolt in Malabar. Modern Asian Studies, 11, 57-99. doi:10.1017/S0026749X00013226

Heimsath, C. H. (1978). The functions of Hindu reformers-With special reference to Kerala. The Indian Economic and Social History Review, XV, 21-39. doi:10.1177/001946467801500102

Heimsath, C. H. (1982). From social reform to social struggle. Man and Development, IV, 29-34.

Houtart, F., \& Lemercinier, G. (1978). Socio-religious reform movements in Kerala: A reaction to the capitalist mode of production. Social Scientist, 6, 25-43. doi:10.2307/3516673

Jeffrey, R. (1974). The social origins of a caste association, 1875-1905: The founding of the S.N.D.P. Yogam. South Asia, 4, 39-59.

Jeffrey, R. (1978b). Matriliny, marxism and the birth of the communist party in Kerala, 1930-1940. Journal of Asian Studies, XXXVIII, 7798.

Kelappan, K. (1925). Vaikam satyagraham. Matrubhumi Onam Special, 42-45.

Kelappan, K. (1932a). Mathavum samudayavum: Mathaparivarthana sramam kondulla dosham (Religion and community: The harms caused by religious conversion). Matrubhumi Weekly, 10, 7-8.

Kelappan, K. (1932b). Mathavum samudayavum: Oru swathantra government cheyyendathenthellam (Religion and community: What should an independent government do). Mathrubhumi Weekly, 10, 4-5.

Kunhuraman, C. V. (1925). Tiyyarku nallathu buddhamatham thanne (Buddhism is better for the tiyyas). Mitavadi Special, II, 6-24.

Menon, D. M. (1999). Houses by the sea: State formation experiments in Malabar, 1760-1800. Economic and Political Weekly, 34, 1995- 


\section{R. MANMATHAN}

2003.

Muralidharan, M. (1996). Hindu community formation in Kerala: Processes and structures under colonial modernity. South Indian Studies, 2, 234-259.

Nambutiripad, E. M. S. (1937). Congress socialist. 7-9.

Nambutiripad, K. S. (1932). Matha parishkaram (Religious reform). Mathrubhumi Weekly, 10, 7-8.
Narayanan, M. G. S. (2011). Malayala manorama. Sunday Supplement, $I X$.

Pulapilly, C. K. (1976).The izhavas of Kerala and their historic struggle for acceptance in the Hindu society. Journal of Asian and African Studies, XI, 24-46. doi:10.2307/3516673

Thampan, M. R. V. (1932). Kshetra pravesanam (Temple-entry). Mathrubhumi Weekly, 9, 5-6. 